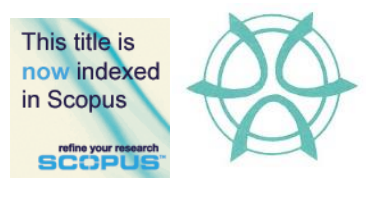

PLANNING MALAYSIA:

Journal of the Malaysian Institute of Planners

VOLUME 16 ISSUE 1 (2018), Page 88 - 95

\title{
THE IMPACT OF ROAD GRADIENT AND TRUCK COMPOSITION ON THE TOLL ROAD TRAFFIC PERFORMANCE
}

\author{
Nahry Yusuf ${ }^{1} \&$ Dwi Setiyadi Sudrajat ${ }^{2}$ \\ ${ }^{1,2}$ Faculty of Engineering \\ UNIVERSITAS INDONESIA
}

\begin{abstract}
Jakarta Outer Ring Road (JORR) is a toll road system that circles the outskirts of Jakarta, where the purpose of this road is to reduce congestion on the streets in Jakarta city centre. However, the high composition of trucks in JORR resulted in congestion of the road, which is hypothesized as attributed by the gradient of this road. This study aims to evaluate the impact of road gradient on truck and the overall traffic performance. Using data obtained from 24-hour traffic recording on selected JORR section, a VISSIM model was constructed to simulate traffic performance on some combinations of traffic and gradient conditions. In terms of macroscopic view point of traffic stream, the simulations showed that road gradient alone insignificantly affected truck speed, as well as the overall traffic speed. Instead, truck composition had more effect on the traffic speed rather than the gradient. In a particular composition of trucks different gradients did not significantly affect traffic speed differently. This implies that any policy to restrict truck access to toll road should depend mainly on the composition of truck itself, not the gradient of the road.
\end{abstract}

Keyword: Trucks, truck composition, road gradient, toll road 
PLANNING MALAYSIA

Journal of the Malaysia Institute of Planners (2018)

\section{INTRODUCTION}

Toll road is generally built to provide a service that is better than the arterial road. The Jakarta Outer Ring Road (JORR) is a toll road system that circles the outskirts of Jakarta, where the purpose of constructing JORR is reduce congestion in the city centre of Jakarta. However, due to the increasing volume of traffic on JORR, its current level of service is less than satisfactory. As an alternative toll road circling the city of Jakarta, JORR currently becomes the main road for freight transport to and from southern, western and eastern part of Jakarta. Therefore, the composition of heavy vehicles in JORR is quite high throughout the day. With the increasingly poor performance of JORR, heavy vehicles (i.e. trucks) are considered to have an enormous share on such condition due to their large dimensions and their relatively slow speeds. Therefore, JORR operator is planning to restrict trucks to use some segments of JORR for certain time window. On the other hand, the logistics users are aggrieved and the aim of constructing the toll road, namely to improve the efficiency of goods distribution becomes questionable.

Prior to enforcing the access restriction system to trucks from using JORR, a review should be conducted to look into other causes of the congestion to find better solution to the problem. Theoretically, one aspect that can degrade performance on JORR is vehicle composition, where high heavy vehicle composition can reduce overall speed of the traffic, especially when it is coupled with steep slopes conditions. Reviews on the traffic performance associated to the road geometry condition, particularly the road gradient, have been aplenty. Bornes and Aakre (2011) developed a model for calculating speed profile for a heavy vehicle uphill in a grade. It is mainly used to decide start and end of passing lanes depending on speed difference between a typical heavy vehicle and passenger cars, and to estimate the influence of grades on the speed and travel time for heavy vehicles on rural roads for use in navigation systems, cost-benefit analysis etc. The model is based on utilized engine power needed to overcome the total running resistance for a specific vehicle. The model is in principle based on physical laws, but there are several factors which make a theoretical description different from real life. The calibration and validation process was carried out using detailed observations of instrumented heavy vehicles where all input data were known. Habtemichael and Luis (2013) studied that the measured speed profile will always contain some noise depending on driver behaviour, power utilization, engine specifications, road geometry, accuracy of observations, etc. Driver behaviour concerning choice of speed, gear, torque, rpm, etc will usually be difficult to model in a realistic way.

Most prior studies were based on the microscopic observation on the performance of individual heavy vehicles (i.e. trucks) in a traffic flow in passing through a certain road gradient. On the other hand, the presence of heavy vehicles in traffic flow may have different effects on traffic performance due to the 
Nahry Yusuf \& Dwi Setiyadi Sudrajat

The Impact of Road Gradient and Truck Composition on the Toll Road Traffic Performance

gradient of the road. In this case the composition of heavy vehicles in traffic flow may have different effects on the performance of the overall flow in different gradient. This study is intended to investigate the impact of road gradient on the traffic performance on JORR in macroscopic way. This study is expected to determine a rationale for route shifting or climbing lane for trucks to avoid steep gradients that can cause disruption to the overall traffic performance.

\section{RESEARCH METHODOLOGY}

Data was obtained through 24-hour traffic recording by video camera on selected JORR section, which was $75 \mathrm{~m}$ in length. The section under consideration was a 4-lane divided road without shoulder (Figure 1). Traffic volume, speed, and density of the section under was generated from traffic record, and the 24 hour observation was sliced into 5-minute observations. For each time slice the volume, speed and density during the 5 minutes were converted into hourly measures. The vehicles were classified into 4 different vehicle types, which were light vehicle, medium vehicle, large bus, and large truck.

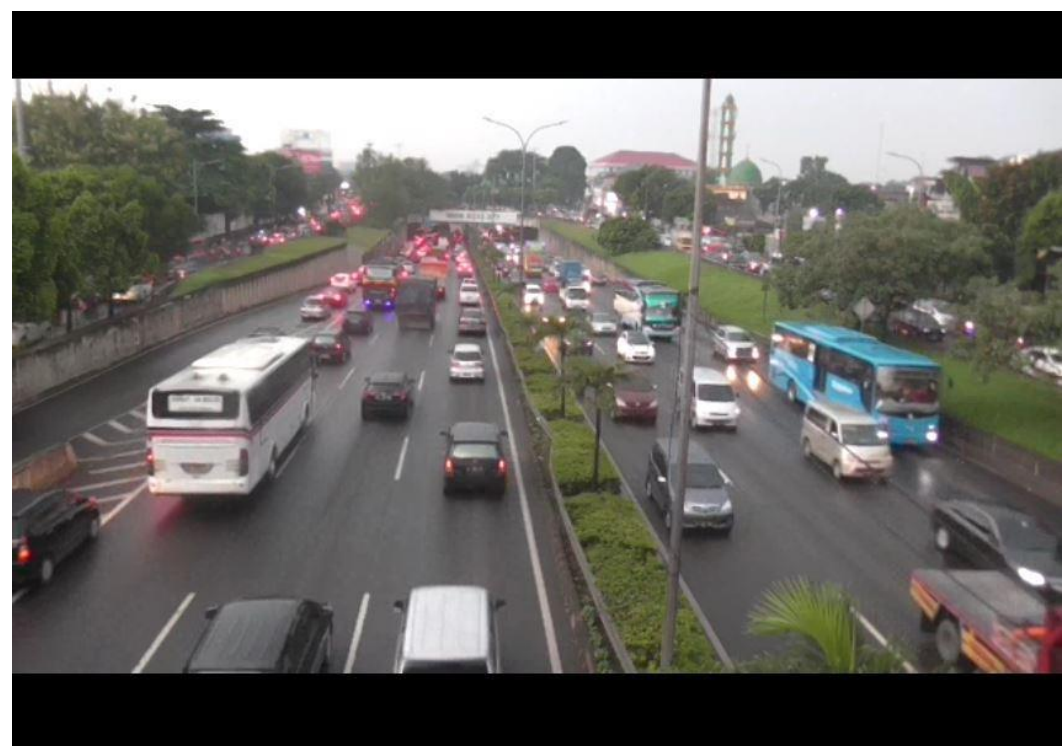

Figure 1: Existing traffic situation at the observed JORR segment

Subsequently, VISSIM model was constructed. VISSIM is a microscopic simulation software package which can be used to simulate traffic (PTG AV, 2011). Model construction consisted of several important stages, namely setting the map, making the road segment, vehicle modelling, distribution speed arrangement, vehicle composition arrangement, setting the number of vehicles input, and setting the drivers' reaction parameter. All the measures were set by trial and error method to arrive to the values that represent the most actual driving 
PLANNING MALAYSIA

Journal of the Malaysia Institute of Planners (2018)

behaviour of the traffic on the road under consideration. In order to test the validity of the model, traffic performance measure resulted from the model was compared with the observed measure which came from the data recording (Park $\&$ Schneeberger, 2003). In this study, the traffic performance measure was represented by the flow along the segment under consideration. Hence, GEH statistics were applied to compare two sets of traffic volume with the criteria shown in Table 1. Using the valid VISSIM model, simulations were done to 5 conditions of road gradient, 2 types of traffic density, and 2 types of heavy vehicle composition to estimate the average speed of the overall traffic and of heavy vehicles for some combinations of those three variables.

Table 1: GEH criteria

\begin{tabular}{ll}
\hline Criteria & Decision \\
\hline GEH $<5,0$ & Model accepted \\
$5,0 \leq \mathrm{GEH} \leq 10,0$ & $\begin{array}{l}\text { Warning: Possibly model is error or poor quality of } \\
\text { data }\end{array}$ \\
GEH $>10,0$ & Model rejected \\
\hline
\end{tabular}

\section{RESULT AND DISCUSSION}

To validate the VISSIM model, the data was grouped into 5 sets with various randomly selected conditions. Table 2 shows the results of validation test with GEH method.

Table 2: Result of validation using GEH method

\begin{tabular}{|c|c|c|c|c|c|c|c|c|}
\hline \multirow{3}{*}{ Time } & \multicolumn{8}{|c|}{ GEH } \\
\hline & \multicolumn{4}{|c|}{ Total Vehicle } & \multicolumn{4}{|c|}{ Average Speed (km/hour) } \\
\hline & LV & MHV & LB & LT & LV & MHV & LB & LT \\
\hline 3:00 & 0.50 & 2.08 & 0.65 & 0.08 & 0.11 & 0.02 & 0.09 & 0.03 \\
\hline 6:00 & 1.13 & 1.13 & 0.70 & 0.07 & 2.07 & 1.87 & 1.60 & 1.08 \\
\hline $12: 00$ & 1.17 & 0.96 & 0.96 & 0.24 & 3.41 & 1.62 & 1.95 & 1.37 \\
\hline $15: 00$ & 2.79 & 1.59 & 0.20 & 0.10 & 3.49 & 1.90 & 2.13 & 1.42 \\
\hline 18:00 & 6.30 & 1.80 & 0.35 & 0.55 & 2.35 & 2.37 & 2.72 & 1.96 \\
\hline
\end{tabular}

From calibration and validation process, it was found that most of GEH values were less than 5 , hence it implied that the driving behaviour parameters that were applied in themodel could represent the actual condition of JORR traffic. In order to see the effect gradient on the speed of both trucks and nontruck, simulations were done on 10 sets of traffic conditions for 5 types of road gradients, i.e. $0 \%, 2 \%, 4 \%, 6 \%$ and $8 \%$ with two types of truck composition, namely $0 \%$ and $20 \%$.

Figure 2a shows the result of simulation on truck speed in which all the inputs related to traffic condition for each of simulation were similar but the gradient. Figure $2 \mathrm{~b}$ shows the result for non-truck speed. They indicate that the 
Nahry Yusuf \& Dwi Setiyadi Sudrajat

The Impact of Road Gradient and Truck Composition on the Toll Road Traffic Performance

speeds tend to decrease as the road gradient increases. The effect of gradient on speed seems more stable on non-trucks rather than trucks.

Furthermore, Figure 3 shows the speed-density diagrams derived from simulation. Regression technique was applied to find the best-fit speed-density model for $0 \%$ of truck and $20 \%$ of trucks. Table $3 \mathrm{a}$ and $3 \mathrm{~b}$ show the mathematical model as well as its coefficient of determination.

In order to assess the significance of the differences among the models, Pearson correlation test was carried out with a significance level $\alpha=0.05$. The test indicated that there were very strong correlations among the models, and there was almost no difference of the models for various types of gradient. It implied that the gradient alone have no effect on the traffic performance, namely speeddensity relationship, for both low and high composition of trucks.

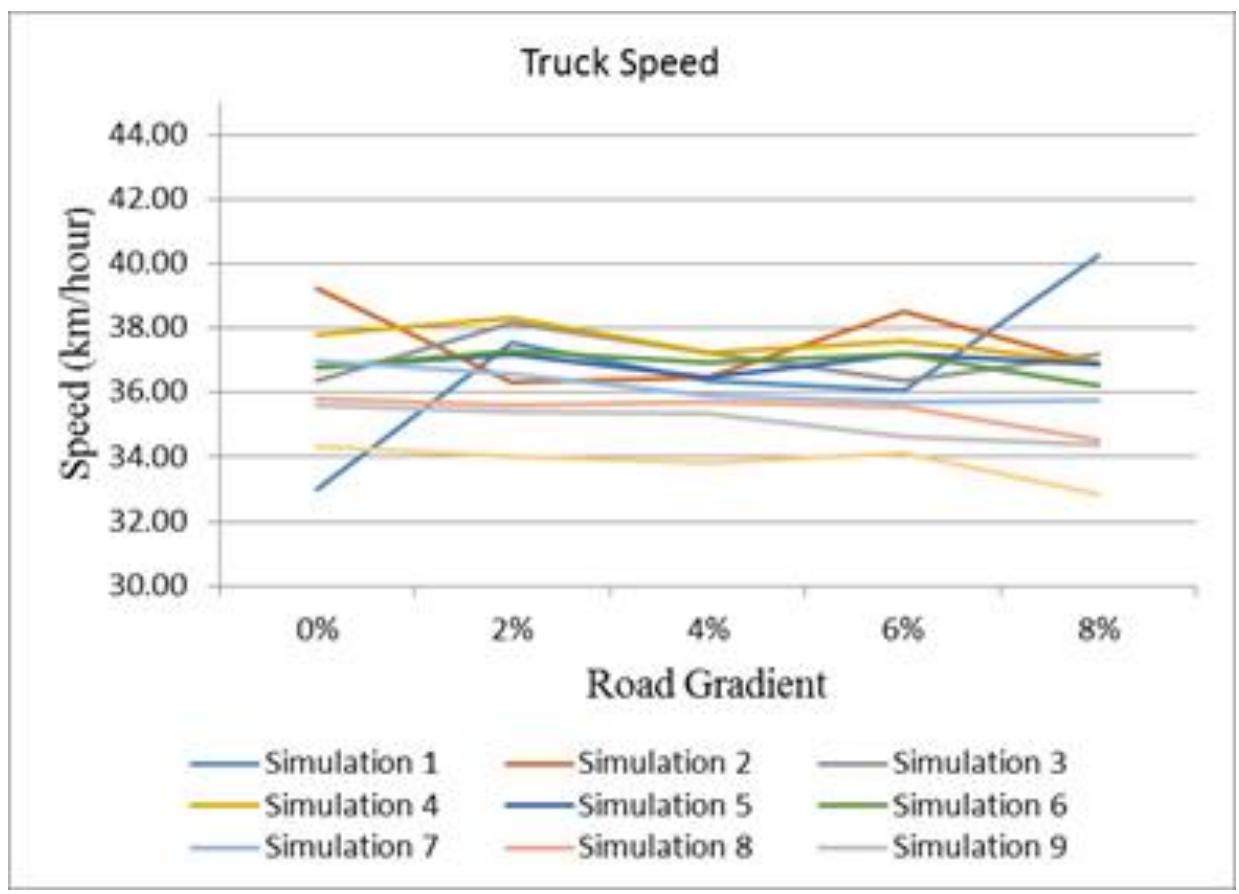

Figure 2a: Truck speed on various gradients 
PLANNING MALAYSIA

Journal of the Malaysia Institute of Planners (2018)

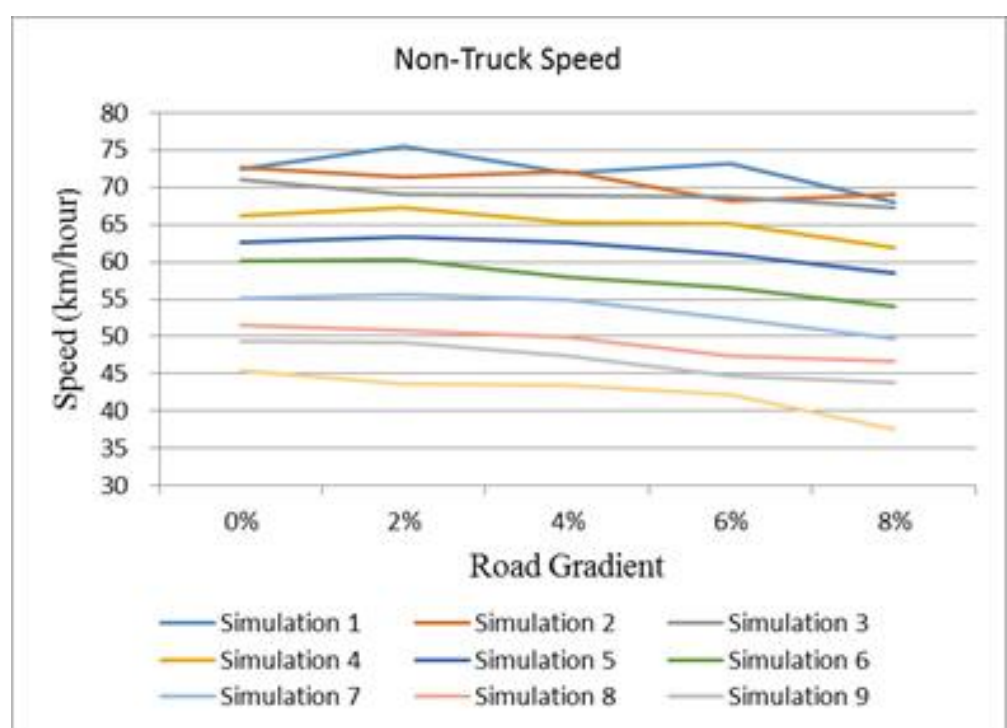

Figure 2b: Non-truck speed on various gradients

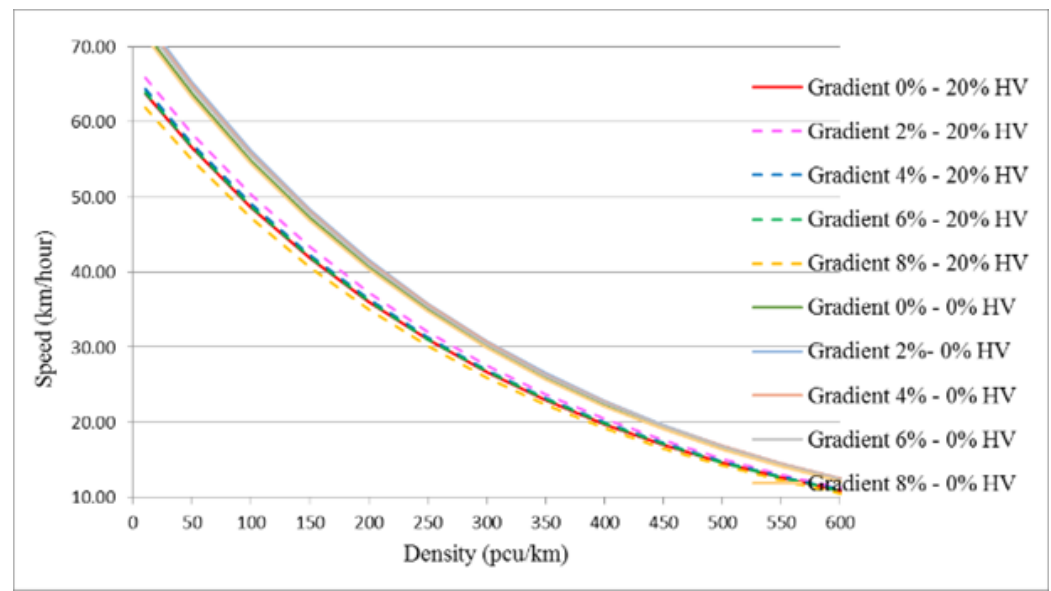

Figure 3: Speed-density model for various gradients and \% of heavy vehicle

Table 3a: Speed-density model for various road gradients and $0 \%$ of truck

\begin{tabular}{lll}
\hline Gradient & Speed-Density Model & $\mathrm{R}^{2}$ \\
\hline $0 \%$ & $u=74.05 e^{-0.003 k}$ & 0.9790 \\
$2 \%$ & $u=75.78 e^{-0.003 k}$ & 0.9874 \\
$4 \%$ & $u=75.36^{-0.003 k}$ & 0.9965 \\
$6 \%$ & $u=74.96 e^{-0.003 k}$ & 0.9855 \\
$8 \%$ & $u=73.53 e^{-0.003 k}$ & 0.9919 \\
\hline
\end{tabular}


Nahry Yusuf \& Dwi Setiyadi Sudrajat

The Impact of Road Gradient and Truck Composition on the Toll Road Traffic Performance

Table 3b: Speed-density model for various road gradients and $20 \%$ of truck

\begin{tabular}{lll}
\hline Gradient & Speed-Density Model & $\mathrm{R}^{2}$ \\
\hline $0 \%$ & $u=65.646 e^{-0.003 k}$ & 0.9913 \\
$2 \%$ & $u=67.924 e^{-0.003 k}$ & 0.9915 \\
$4 \%$ & $u=66.301 e^{-0.003 k}$ & 0.9937 \\
$6 \%$ & $u=65.831 e^{-0.003 k}$ & 0.9847 \\
$8 \%$ & $u=63.755 e^{-0.003 k}$ & 0.9901 \\
\hline
\end{tabular}

In addition to the correlation test, the mathematical difference among the speeds of various gradients and various densities was determined and the results are shown in Table $4 \mathrm{a}$ and $4 \mathrm{~b}$. Those simulations confirm the law of relationship of speed-density, which is the higher the density, the lower the speed is. They also confirmed that the more trucks on traffic stream, the lower the speed of the overall traffic. Regarding the road gradient, the simulation indicated that for certain density the higher the gradient (the steeper the road) the lesser the speed was, and this is valid for low and high composition of trucks. However, the effect of gradient on speed seemed insignificant. It may be caused by the view point of this VISSIM simulation, which is macroscopic viewpoint of traffic stream rather than microscopic one. The results of simulation represented the characteristics of the overall traffic rather than individual or group of individual vehicles.

Table 4a: Speed differences for various densities and road gradients and $0 \%$ heavy vehicle

\begin{tabular}{lllll}
\hline \multirow{2}{*}{ Density $(\mathbf{p c u} / \mathbf{k m})$} & \multicolumn{4}{l}{ Speed Difference (compare to speed of 0\% } \\
\cline { 2 - 5 } & $\mathbf{2 \%}$ & $\mathbf{4 \%}$ & $\mathbf{6 \%}$ & $\mathbf{8 \%}$ \\
\hline 10 & 1.677 & 1.274 & 0.879 & 0.509 \\
100 & 1.280 & 0.973 & 0.671 & 0.389 \\
200 & 0.948 & 0.721 & 0.497 & 0.288 \\
300 & 0.703 & 0.534 & 0.368 & 0.213 \\
400 & 0.521 & 0.396 & 0.273 & 0.158 \\
500 & 0.386 & 0.293 & 0.202 & 0.117 \\
600 & 0.286 & 0.217 & 0.150 & 0.087 \\
700 & 0.212 & 0.161 & 0.111 & 0.064 \\
\hline
\end{tabular}

Table 4b: Speed differences for various densities and road gradients and $20 \%$ heavy vehicle

\begin{tabular}{lllcc}
\hline \multirow{2}{*}{ Density (pcu/km) } & \multicolumn{4}{c}{ Speed Difference $($ compare to speed of 0\% gradient) } \\
& \multicolumn{5}{c}{$\mathbf{k m} / \mathbf{h r})$} & \\
\cline { 2 - 5 } & $\mathbf{2 \%}$ & $\mathbf{4 \%}$ & $\mathbf{6 \%}$ & $\mathbf{8 \%}$ \\
\hline 10 & 2.211 & 0.636 & 0.180 & 1.835 \\
100 & 1.688 & 0.485 & 0.137 & 1.401 \\
200 & 1.250 & 0.359 & 0.102 & 1.038 \\
300 & 0.926 & 0.266 & 0.075 & 0.769 \\
400 & 0.686 & 0.197 & 0.056 & 0.570 \\
\hline
\end{tabular}


PLANNING MALAYSIA

Journal of the Malaysia Institute of Planners (2018)

\begin{tabular}{lllll}
\hline 500 & 0.508 & 0.146 & 0.041 & 0.422 \\
600 & 0.377 & 0.108 & 0.031 & 0.313 \\
700 & 0.279 & 0.080 & 0.023 & 0.232 \\
\hline
\end{tabular}

\section{CONCLUSION}

In terms of macroscopic view point of traffic stream, the VISSIM model simulation results have shown that the road gradient alone insignificantly affects the speed of groups of truck, as well as speed of the overall traffic. The truck composition has more effect on the traffic speed rather than the gradient, particularly on low to medium density situation. On particular composition of trucks, different gradients have not resulted in significantly different effects on the traffic speed. These imply that any policy to restrict truck access to toll road should depend mainly on the composition of truck itself, not the gradient of the road. In case of traffic congestion where the road gradient is relatively gentle but the composition of truck is relatively high, it may be the time to apply truck access restriction, and when the gradient is relatively steep but the truck composition is quite low it is not judicious to restrict the truck to overcome the congestion problem.

\section{ACKNOWLEDGEMENT}

This research is supported by research funds made available through the National Strategic Research Scheme of Directorate General of Research Strengthening and Development of Ministry of Research, Technology and Higher Education of Indonesia.

\section{REFERENCES}

Børnes, V., \& Aakre, A. (2011). Description, validation and use of a model to estimate speed profile of heavy vehicles in grades. Procedia Social and Behavioral Sciences, 16, 409-418.

Habtemichael, F. G., \& Luis, P. S. (2013, January) Sensitivity analysis of VISSIM driver behavior parameters on safety of simulated vehicles and their interaction with operations of simulated traffic. In Transportation Research Board 92nd Annual Meeting. January 13-17, 2013, Washington DC, USA.

Park, B., \& Schneeberger, J. D. (2003) Microscopic simulation model calibration and validation; Case study of VISSIM simulation model for a coordinated actuated signal system. In Transportation Research Record: Journal of the Transportation Research Board, 1856. DOI: 10.3141/1856-20

PTV AG (2011). VISSIM 5.30-05 user manual. Germany. Karlsruhe: PTV AG. 


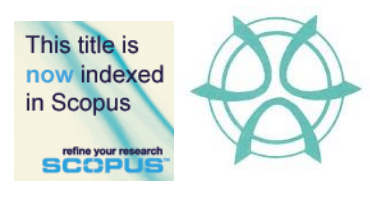

PLANNING MALAYSIA:

Journal of the Malaysian Institute of Planners

VOLUME 16 ISSUE 1 (2018), Page 96 - 104

\title{
MOSQUE: A STATEMENT OF CITIZENSHIP
}

\author{
Abdul Razak Sapian ${ }^{1}$, Mohd Noorizhar Ismail' ${ }^{2}$, Mizanur Rashid ${ }^{3}$, \& Wan Nurul \\ Mardiah Wan Mohd Rani ${ }^{4}$ \\ ${ }^{1,2}$ Kulliyyah of Architecture and Environmental Design \\ INTERNATIONAL ISLAMIC UNIVERSITY MALAYSIA, MALAYSIA \\ ${ }^{3}$ School of Architecture and Built Environment, \\ UNIVERSITY OF ADELAIDE, AUSTRALIA \\ ${ }^{4}$ UTM Razak School of Engineering and Advanced Technology \\ UNIVERSITI TEKNOLOGI MALAYSIA, MALAYSIA
}

\begin{abstract}
Mosque is referred to as a place for Muslim's congregational prayers, a community centre, and a frontage to the Muslim's world. Mosque from the start was intended as a sanctuary and home to the Muslims where they can affiliate in their lives. In Australia, the Afghan cameleers have established the major mosques as they were among the early Muslim settlers of the country after the Makassar Muslims. Afghans Cameleers in Australia are majority Muslims in a faraway land of Afghanistan, who migrated to this place of unfamiliarity in order to place themselves in the society while searching for wealth in sustaining and building their reputation in their homeland. This research seeks to explore the idea of citizenship through the concept of belonging and how it translates to architecture and the Islamic built environment. To express the sense of belonging and citizenship in a land where they are unaccepted, the Afghans resort to creating a building of such that would represent their struggles, identity, religion and legacy to be accepted and represent their citizenship. This research will study the elements that result to the citizenship of the Muslim Afghans in Australia. The citizenship approach will focus on the social inference rather than political or constitutional approach as the 1901 immigration law dictates that these people will never be naturalized.
\end{abstract}

Keyword: mosque, citizenship, architecture, islamic built environment, sense of belonging 
PLANNING MALAYSIA

Journal of the Malaysia Institute of Planners (2018)

\section{INTRODUCTION}

Mosque is known to be a religious building dedicated to Muslims as a place for congregational prayers and other religious activities. At least once a week, every Friday, Muslim community will engage for Friday congregational prayers that was designed to continuously tie the bond among the Muslim community within the surrounding area and those who affiliates with the mosque. A place to call home, or home is where the heart is, represents the longing of a person to their comfort zone and familiarity. These quotes are often found from people who travel far away from their birthplace or maybe just a traveller going outstation for a few days. Being far away from home makes one search for familiarity, comfort and similarity in all aspects. In order to cure this longing, one usually simulates this familiarity and similarity in one's understanding. Hence, the story of the Muslim cameleers in Australia and the assimilation of the Afghans and the locals through the institution of mosque. Afghan cameleers in Australia are majority Muslims in a faraway land of Afghanistan, who migrated to this place of unfamiliarity in order to place themselves in the society while searching for wealth in sustaining and building their reputation in their homeland (Cleland, 2000). Here, they are different from the European settlers, resulting in being displaced among the settlers. They started in the rims of towns and cities and slowly try to assimilate into the community with their reputations, services and respect towards the settlers. The Afghans created small communities and mosque in their communities as a place to represent themselves and as a method of assimilating and networking among themselves (Scriver, 2004).

This research seeks to explore the idea of citizenship through the concept of belonging and how it translates to architecture and the Islamic built environment. This research addresses how the Afghans struggles in establishing mosque as a building that represents state of citizenship especially during 1901 where White Australia Policy was introduced affecting any chances of the Afghans to be naturalized into the newly formed Australia. To express the sense of belonging and citizenship in a land where they are unaccepted, the Afghans resorted to creating buildings of such that would represent their struggles, identity, religion and legacy to be accepted and represent their citizenship. This research study the elements that result to the citizenship of the Afghans in Australia. The citizenship approach will concentrate on the social inference rather than political or constitutional approach as the 1901 immigration law dictates that these people will never be naturalized. Currently there is limited research on the historical growth of Muslim cameleers' settlement in Australia. According to Rashid and Bartsch (2014), most studies focused on socio-cultural and anthropological issues that do not address the links with other mosques that were once scattered around the outback of inland Australian. Hence, a thorough research on the relationship of mosques and the process of gaining sense of belonging and citizenship should be done in order to further understand this 
Abdul Razak Sapian, Mohd Noorizhar Ismail, Mizanur Rashid, \& Wan Nurul Mardiah Wan Mohd Rani Mosque: A Statement of Citizenship

displaced people in the context of Australia and how they have impacted the built environment.

\section{THE ESTABLISHMENT OF MOSQUES}

Mosque, a place to gather for prayers, a community centre, an embassy and a frontage to the Muslims world. Mosques have been made as an institution that represents the Muslim community ever since the time of the Prophet Muhammad (peace be upon him). Mosque was the first structure built by the prophet after the great migration from Mecca and Medina as a place that the Muslims could be comfortable to congregate and practice their daily prayers (Islam, 2012). Mosque from the start was intended as a sanctuary and home to the Muslims where they can affiliate in their lives.

\section{Mosques in Australia}

The mosque institution came into picture in Australia during the peak of the cameleers' immigration between the late 1800s to the early 1900s (Jones \& Kenny, 2010). This was the result of the prosperity and affordance of these cameleers that had established in the society quite well. Cameleers such as Faiz and Tagh Mohamet, Abdul Wade and Mohamet Allum were well known in the European community as entrepreneurs, socialites and medicine practitioners that contributed towards the community and embodies the Australian patriotism of serving and contributing to the country (Scriver, 2004). These Afghan names did not only resonate locally but was well known among other territories on their reputations and connections that helped build up the nation of Australia (Bartsch, 2015).

Customs Authorities summarized that there were seven active mosques in Western Australia in 1920, three in South Australia (one in Adelaide, two in Marree), two in Broken Hill New South Wales and one in Holland Park in Queensland. This was further verified by A.H Pitchard, Secretary of the Australian Indian Society to a query from Department of External Affair (Rashid $\&$ Bartsch, 2014). These entire mosques are active Afghan mosques.

Perth and Adelaide Mosques are two religious buildings that were built purposely as a magnet and as a projection of the Muslim community in a foreign setting. These buildings were the result of a need and as a front to the Muslims in displaying their beliefs, their practice and their faith. Afghan cameleers popularly practiced Islam during their migration to Australia in 1860, which was due to the need of camels for exploration of Central Australia (Stevens, 2002). Before this Islam has step into Australia through Makassar tradesmen from Indonesia who traded seashells with the aborigines in Northern Territory in the early 1200's (Stevens, 2002).

The cameleers have contributed in exploring inland Australia from the ill-fated Burke and Wills expedition to other big expeditions. These cameleers 
are also responsible in the development of rural Australia by laying the base line of transportation such as telegraph and train lines from Port Augusta to Alice Springs, thus making them very important in the society. However, the life and practices of cameleers were known within their profession and networks but little about their religion and how they portray their religion. Islam was first known as Mohammedan and mosques were called Mohammedan churches and mullahs as Mohammedan priests. They were known to pray at certain times of the day (Pamela, 2005) and avoid alcohol and pork. Mohammedan churches were always treated as any other churches but the function and relationship of this building to the cameleers were much deeper.

\section{CITIZENSHIP}

Citizenship is a modern concept, which was the product of the French revolution and its aftermath (Turner, 1993). Turner (1993) suggests that the concept of citizenship is a modern concept and continuous, and it was developed out of a peculiar conjuncture of cultural and structural conditions which may be peculiar to the west (Roche, 1987). This idea of citizenship was based on western idea of colonialism and monetarism. The expansion and colonializing lands has resulted into the introduction of citizenship in order to secure a place and its resources limited to certain few. The idea of citizenship was also mostly influenced by the rising bourgeois culture and urban civilization that was widely explored by Kalberg (Turner, 1993).

Citizenship can be divided into two major definitions. According to Turner (1993), citizenship is divided into Social and Political. Socially Citizenship is a modern binding of nationality and religion in the sociology perspective that also represents social identity (Turner, 1993). Social citizenship is based on institution of welfare state that buffer against the inequalities of marketplace and class system. Politically, and constitutionally, citizenship is a bundle of rights and duties relating to an individual as a member of a political community (Turner, 1993). These rights are usually dictated to one who is holding a passport or tax paying person of a state, which is under the dominant paradigm of Western social democracy (Turner, 1993).

The idea of citizenship in Australia was brought forth by the introduction of immigration restriction act 1901, which is also known as Australia white policy. This was in line with the announcement of independent Australia 1901. The newly formed government of six colonies decided to apply this new immigration law as a way of controlling resources, controlling population of nonEuropeans and as to limit business competition between non-Europeans and Europeans traders in Australia (Humphrey, 2010). The method applied in the immigration act is to have a dictation test in any European languages lowering the chances of non-European speakers to achieve citizenship in Australia. 
Abdul Razak Sapian, Mohd Noorizhar Ismail, Mizanur Rashid, \& Wan Nurul Mardiah Wan Mohd Rani Mosque: A Statement of Citizenship

The immigration restriction act was based on the desperation of the six Australian colonies after the great drought of 1890 that resulted in violent industrial strikes (NSW Migration Heritage Centre, 2010). Furthermore by 1890 , 70 percent of the population was born in Australia and growing nationalist sentiment pushing for the unification of the six colonies. The six colonies were more connected than before through overland telegraph line, submarine telegraph and ground transportation of goods that had gone beyond borders of the six colonies. The discovery of gold and precious metals in Australia had attracted Chinese prospectors into Australia resulting to head-on competition between them and the locals. With main ground transportation between major cities of Western Australia, South Australia and New South Wales dominated by the cameleers resulting in uneasiness to Europeans settlers and by uniting into one nation under one immigration law may restrict all the competition from migrating Asians.

Uniting six colonies was a huge task with many negotiations and disputes needed to be addressed. However the need of unification outweighs the differences. Many sessions of conferences and meetings resulted in the 1900 agreement for federation. Finally, on 1st January 1901, Commonwealth Australia was proclaimed in a grand ceremony in Sydney's Centennial Park. The proclamation of Commonwealth Australia however was limited to their own parliament but without control on foreign policy or defence. These two elements were exclusively controlled by Britain.

\section{The Implications to the Afghan Muslim Cameleers and Immigrants}

It is expressed that issues of sense of belonging is often associated with immigrants. The issues associated with sense of belonging have led the immigrants to experience hardship and struggle to fit in within a new environment (Nagel, 2011). The journey of the Afghans towards gaining the sense of belonging and citizenship has been an emotional journey. Starting from their establishment in Inland Australia as cameleers, Afghans were responsible in helping discovering and developing rural Inland Australia with their camels. Arriving in 1860 they served the country diligently for forty-one years until 1901 (Nagel, 2011). However, they were denied citizenship by the Australian 1901 immigration law.

\section{TRANSLATION OF CITIZENSHIP STRUGGLE TO ARCHITECTURE AND THE ISLAMIC BUILT ENVIRONMENT}

The implication of a mosque to the built environment is wide-ranging. From an urban planning point of view, mosque is regarded as a built urban form that serves the community similar to the role of a community / civic centre. In relation to community sustainability, mosque is the right place that can promote social cohesion. The concept of social cohesion is central to social sustainability as it 
focuses on to foster civic participation, strengthen community networks, and promote community tolerance and to purport shared sense of social tolerance.

The translation of citizenship struggle to architecture and the built environment is based on certain elements that are defined by the relationship of human sense of establishment and the sense of belonging. These elements are the driving forces behind the architecture that is erected in order to find approval of a way from the local population and acceptance of their existence in the land. Drawing from the idea presented by Phillips (2014), Feldman (1990) and Gale (2004), the researchers formulated a concept of social citizenship that impacted the architecture and the built environment as shown in Figure 5.

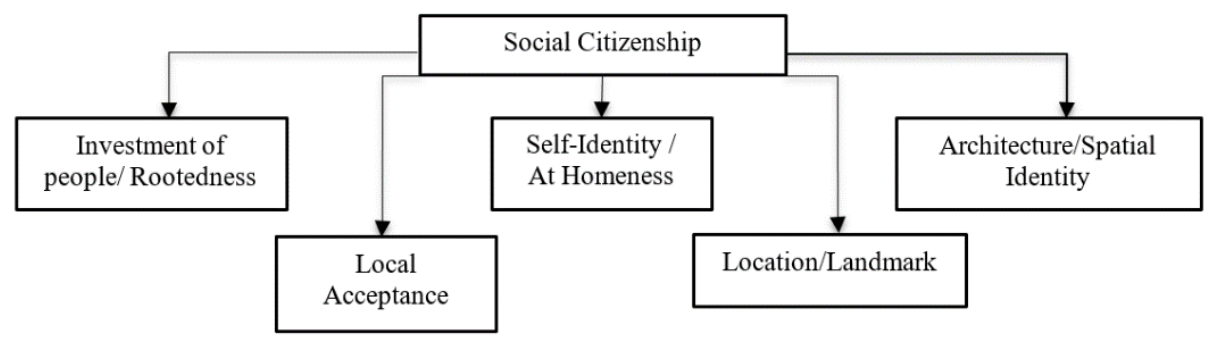

Figure 1: Concept of social citizenship Source: Modified from Phillips (2014), Feldman (1990) and Gale (2004).

In Islam, a mosque does not require a specific edifice, as prayer can be observed anywhere as long as one faces Mecca (Erzen, 2011). A mosque may take any form as long as the core functionality stays the same. This was well practiced by the Afghan cameleers in Australia. However, there were exceptions in the case of the Afghan cameleers as the morphology of the mosque relates to the desire to establish citizenship and to create a sense of belonging in their community. Mosques in Australia started as simple rectangular plans with a mihrab facing Mecca using basic materials as to fulfil the need of congregational prayers (Schinasi, 1980). The architecture of the mosques was presented in a more utilitarian approach with a basic rectangular floor plan and a mihrab facing Mecca. This was well replicated in all inland mosques with variety of sizes, depending on the size of the congregation and location of the mosques. However, this had changed when the Afghans decided to enter the city. The expression of sense of belonging was poured physically towards the mosques. Tuan (1977) describes that the sense of attachment through monuments, shrines and buildings is a sign of identity and as an expression of attachment to the homeland. The Afghan cameleers had invested in creating mosques that invoked the sense of belonging by creating elements that reminded them of their homeland. The architecture of Adelaide mosque was well spelled out in creating a tangible realm that reflects the cultural image and expression of the characteristics that 
Abdul Razak Sapian, Mohd Noorizhar Ismail, Mizanur Rashid, \& Wan Nurul Mardiah Wan Mohd Rani Mosque: A Statement of Citizenship

symbolize the patterns and movements of social and personal life reflecting the sense of belonging (Tuan, 1977). The Adelaide mosque, even humble in nature, still installs the approach of the image of paradise in Islamic architecture. This image is represented by water features and vegetation symbolizing paradise as described in verses of the Quran that describe the enchantment of paradise to those who follows their duty to God (Erzen, 2011). This small touch of paradise in a humble building is a representation of the Afghans approach to architecture of the homeland and one-step to citizenship in Adelaide. Perth Mosque embodies a sense of architecture that is different from Adelaide mosque. The architecture of Perth Mosque uses the approach of Urban Sculpture. The Perth Mosque symbolizes a sculptural form that stands out in urban space (Erzen, 2011). The design and approach of Perth Mosque was highly sculpted with details that are non-ever applied in any mosque in Australia. Located in a prominent street in Perth, the mosque was intended to be a sculptural landmark of the area. Perth Mosque was built higher than ground, easily viewed even though located behind a wall. The sculpted small domes that crown the mosque are clearly visible from Williams Street, reflecting the landmark created by the Afghan cameleers. The style imposed on the design of the Perth mosque is a reference of guidance and creation of social reference creating a feeling of belonging to the Afghans and locals.

The architecture of mosques represented by the Afghans in Australia is morphology of sense of belonging represented through the changes of places. The architecture of mosques in inland Australia embodies simplicity and utilitarian as the sense of belonging was provided by the landscape similarity that reminds them of their place of origin. However, city mosques were of different approach as the urban scene has different landscape and the expression of sense of belonging can only be achieved through architecture.

\section{CONCLUSION}

Tracing the journey of the Muslim Afghan cameleers has brought an insight to the development of the inland Australia and how they have contributed to the establishment of mosques and the Muslim community. In particular, the establishment of mosques had marked a statement that Muslim community was well accepted and they had managed to place a landmark to signify an Islamic built environment as part of Australia. This research has also elaborated that the establishment of the mosques is part of the process for them to have sense of belonging, which later, help them claim the citizenship if not through the constitutional, but through social means.

As stated in the beginning of the paper, it is important to understand the journey of the Afghan cameleers in instituting a form of citizenship in Australia. The Afghans had contributed in the development of inland Australia since 1860 but were denied the right to naturalize by the constitution of Australia. The 
hardship and struggles in establishing a form of citizenship as to symbolize their contribution to Australia and as a mark of existence of their people ever existed in Australia. It was only through the establishment of architecture in the form of mosques that they had the opportunity to associate themselves as part of the Australian community thus gaining social citizenship. Drawing from this narrative study, further exploration on the research is essential to capture the detail evidence of contact between Afghan Muslims and local community and the acceptance of the Afghans Muslims by the community. It is also important to illustrate the morphological changes of the mosques in relation to the changing of eras and location symbolizing the journey towards social citizenship.

\section{ACKNOWLEDGEMENT}

The authors would like to acknowledge the International Islamic University Malaysia and the University of Adelaide for funding this research through the Australian Research Council (ARC) Linkage Project (LP130100859).

\section{REFERENCES}

Bartsch, K. (2015). Building identity in the colonial city: The case of the Adelaide Mosque. Contemporary Islam, 9(3), 247-270.

Cleland, B. (2000). The Muslims in Australia: A brief history. Wembley UK: Islamic Human Rights Commission.

Erzen, J. N. (2011). Reading mosques: Meaning and architecture in Islam. Journal of Aesthetics and Art Criticism, 69(1), 125-131.

Feldman, R. M. (1990). Settlement-identity psycological bonds with home places in a mobile society. Environment and Behaviour, 22(2), 183-229.

Gale, R. (2004). The multicultural city and the politics of religious architecture: Urban planning, mosques and mean-making in Birmingham, UK. Built Environment, $30(1), 30-44$.

Humphrey, M. (2010). Securitisation, social inclusion and Muslim in Australia: The dynamics of exclusion and inclusion. Melbourne: Melbourne University Press.

Islam, M. A. (2012, February). The Prophet's Mosque in Madina (623 and 632 AD): Reexamination of Creswell's plans based on Muslim sources. International Seminar on Architecture: Education, Practice and Research 2012. February 24, 2012, Dhaka, Bangladesh.

Jones, P., \& Kenny, A. (2010). Australia's Muslim cameleers: Pioneer of the inland 1861's to 1930. Kent Town, South Australia: Wakefield Press.

Nagel, C. (2011). Belonging. In V. J. Del Casino Jr., M. E. Thomas, P. Cloke and R. Panelli (Eds). A companion to social geography (pp.108-124). Blackwell Publishing Ltd.

Pamela, R. (2005). In the tracks of the camelmen: Outback Australia's most exotic pioneers. Henley Beach, S. Australia: Seaview Press.

Phillips, D. (2014). Claiming spaces: British Muslim negotiations of urban citizenship in an era of new migration. Transactions of the Institute of British Geographers, $40(1), 62-74$. 
Abdul Razak Sapian, Mohd Noorizhar Ismail, Mizanur Rashid, \& Wan Nurul Mardiah Wan Mohd Rani Mosque: A Statement of Citizenship

Rashid, M., \& Bartsch, K. (2014). Architecture of the Adelaide Mosque: Hybridity, resilience and assimilation. Traditional Dwellings and Settlements Review, XXV(II), 65-75.

Roche, M. (1987). Citizenship, social theory and social change. Theory and Society, 16, 363-399.

Schinasi, M. (1980). The Afghans in Australia. The Asia Society (Occasional Paper \#22). New York.

Scriver, P. (2004). Mosques, Ghantowns, and cameleers in the Settlement History of Colonial Australia. Fabrications, 13(2), 19-41.

Stevens, C. (2002). Tin mosques \& ghantowns : A history of Afghan cameldrivers in Australia. Alice Springs, NT: Paul Fitzsimons.

Tuan, Y. F. (1977). Space and place. Minnesota, USA: University of Minnesota Press.

Turner, B. S. (1993). Citizenship and social theory. London: Sage Publication.

NSW Migration Heritage Centre (2010). Retrieved May 01, 2015, from http://www.migrationheritage.nsw. gov.au/ homepage/index.html 